\title{
MENAKAR ULANG FIKIH ABORSI PERSPEKTIF M. QURAISH SHIHAB (Kajian Metodologis)
}

\author{
Uzlah Wahidah Maulidiyah \\ Institut Agama Islam Al-Qodiri Jember \\ uzlabimut@gmail.com
}

\begin{abstract}
The discussion about abortion is very interesting, in some previous studies the concept of reproduction is the legality of abortion that very controversial. There are some contemporary scholars who have an interesting view of abortion, one of them is an Indonesian professor, M. Quraish Shibab. He wrote about abortion in one of the subthemes of his book. Against this phenomenon the writer who has educational backgrounds interested in providing an analysis of the methodology used by $M$. Quraish Shibab in making very controversial decisions especially about abortion. The reason for this istinbath methodology that will describe in this paper.
\end{abstract}

\section{Keywords: Abortion, M. Quraish Shihab, Tafsir al-Misbah}

\begin{abstract}
Abstrak
Pembahasan tentang aborsi sangat menarik, pada beberapa penelitian sebelumnya konsep reproduksi adalah legalitas aborsi yang sangat kontroversial. Ada beberapa ulama kontemporer yang memiliki pandangan menarik tentang aborsi, salah satunya adalah Guru Besar Indonesia M. Quraish Shihab. Dia menulis tentang aborsi di salah satu sub-tema bukunya. Terhadap fenomena tersebut penulis yang berlatar belakang pendidikan tertarik untuk memberikan analisis tentang metodologi yang digunakan oleh M. Quraish Shihab dalam pengambilan keputusan yang sangat kontroversial khususnya tentang aborsi. Alasan metodologi istinbath inilah yang akan diuraikan dalam tulisan ini.
\end{abstract}

Kata Kunci : Aborsi, M. Quraish Shihab, Tafsir al-Misbah 


\section{Uzlah Wahidah Maulidiyah}

\section{Pendahuluan}

Al-Quran tersusun dengan kosa kata bahasa Arab (QS. Yusuf (12): 2) kecuali beberapa kata asing yang masuk di dalamnya karena akulturasi. ${ }^{1}$ Banyak faktor dipilihnya bahasa Arab sebagai bahasa AlQuran, di antaranya adalah keunikannya yang tercermin pada susunan kata dan akar kata. Kosa kata bahasa Arab mempunyai dasar tiga huruf mati dan dapat dibentuk dengan berbagai bentuk. ${ }^{2}$ Al-Quran bila diterjemahkan ke dalam bahasa Inggris, India, Indonesia atau yang lain, bukan lagi Al-Quran, hal tersebut dikarenakan sudah ada perbedaan antara maksud yang diinginkan dan maksud yang

${ }_{1}$ Diantara kosa kata Al-Quran yang mu'arrab adalah yaqut, yasin, yasuddun, lihat Jalaludin al-Suyuti, al-Itqan fi Ulum alQur'an, (Kairo: tt, th) Juz I, 136-141. Lihat juga Muhammad Rawwas Qalahji, Lughat Arab, Lubgat al-Arabi al-Mukhtarah (Dar al-Nafais, tt), 21 dan 30.

2 Misalnya dari ketiga huruf adalah lafadz qala, yakni qaf, wawn dan lam, dapat melahirkan enam bentuk kata dan semua kata tersebut mempunyai beragam makna, lihat M. Quraish Shihab, Esklikopedia Al-Qur'an: Kajian Kosa kata (Jakarta: Lentera Hati, 2007), vii. sebenarnya ada dalam ruh ayat tersebut.

Salah satu masalah yang menjadi problem sosial yang itu juga harus dipecahkan oleh AlQuran sebagai wahyu yang universal adalah masalah wanita. Salah satu problem yang sampai saat ini selalu menjadi perdebatan adalah tentang konsep aborsi. M. Quraish Shihab dalam bukunya yang berjudul Perempuan menyinggung tema ini. Tema aborsi menurut Quraish Shihab harus diberikan pemahaman yang komprehensif.

Hingga saat ini perempuan yang mengalami kehamilan yang tidak dikehendaki dan berakhir dengan pemberhentian kehamilan selalu dalam posisi yang terus dipersalahkan, baik secara normatif agama dan norma kemasyarakatan. Seharusnya dengan tingginya angka kematian yang terjadi akibat aborsi yang ilegal menjadi salah satu agen- 
Vol. 12, No. 2, Oktober 2019

p-ISSN:2086 -0749

e-ISSN:2654-4784

da penting pemerintah untuk menuntaskan problem sosial ini. ${ }^{3}$

Bahwa dalam Islam mengenal hak reproduksi, Islam sebagai agama yang rahmatan lil 'alamin, sebenarnya mempunyai konsep yang indah dalam hal dan wacana tentang hak reproduksi. Secara historis, hak reproduksi sudah menjadi etika global dan telah di tuangkan dalam Konferensi Perempuan sedunia di Mexico City pada tahun 1970. Juga pada Konferensi Perempuan ke III di Nairobe tahun $1985 .{ }^{4}$ Dalam hal tataran Internasional WHO sebagai salah satu badan yang berwenang dalam bidang kesehatan dunia, memberikan definisi bahwa kesehatan reproduksi adalah kesehatan fisik, mental, dan sosial yang utuh dan bebas penyakit atau kecacatan. Da-

\footnotetext{
${ }^{3}$ Maria Ulfa Anshor, Fikih Aborsi Wacana Penguatan Hak Reproduksi Perempuan (Jakarta: Kompas, 2006), 1.

${ }^{4}$ Maria Ulfa Anshor, Fikih Aborsi, 2.
}

lam aspek yang berhubungan dengan hal reproduksi, fungsi dan proses. Sebagai negara berkembang, Indonesia juga merupakan negara yang ikut ambil bagian dalam meratifikasi Undang-Undang tentang hak reproduksi. Hal ini tertuang dalam UU Republik INDONESIA nomer 7 Tahun 1984 pasal 12 tentang pengesahan konvensi mengenai penghapusan segala bentuk diskriminasi terhadap perempuan.

Kalau kita telisik lebih mendalam kajian tentang hak-hak reproduksi itu menyangkut kesehatan perempuan di antaranya adalah perempuan dapat menentukan jumlah kehamilan yang diinginkan sesuai dengan kesehatannya. Dalam agama Islam hak-hak Reproduksi mempunyai legitimasi yang penuh, misalnya dapat kita baca dalam QS. Al-Ahqaf (46): 15): 


\section{Uzlah Wahidah Maulidiyah}

"Kami pesankan kepada manusia untuk berbuat baik kepada ibu dan bapaknya, ibunya telah mengandungnya dengan susah payah, dan melabirkannya juga dengan susab payah dan menyapibnya selama tiga puluh bulan."

Melihat hal itu maka adanya persepsi atau pandangan menempatkan wanita dalam objek seksualitas dalam satu sisi dan objek kesalahan di sisi lainnya yang hal tersebut terkait dengan hak-hak reproduksi. Termasuk di dalamnya adalah persoalan aborsi. Hal ini adalah upaya untuk mengkaji fiqih aborsi alternatif yang menguatkan hak-hak perempuan serta reproduksi perempuan. ${ }^{5}$ Misalnya adalah kasus pemerkosaan, yang jelas pihak perempuan adalah korban yang harus menanggung malu dan aib, baik secara medis maupun psikis. Untuk kasus seperti ini perlu diambil solusi yang bijak, korban pemerkosaan yang telah hamil dan terpaksa melakukan aborsi seharusnya

${ }^{5}$ Maria Ulfa Anshor, Fikih Aborsi, 7. mendapat perlindungan hukum serta pembersihan nama baik dari hinaan masyarakat, karena secara nyata mereka bukan pelaku akan tetapi korban dari kebiadaban lakilaki yang tidak bertanggung jawab. Yang menarik adalah pemahaman masyarakat dengan fikih klasik yang nyata bawah produk fiqh klasik ada "sebagian" yang bias gender masih dibuat pegangan erat untuk menjustifikasi hal tersebut. Realitas ini seharusnya sudah berangsur-angsur dihapus dari norma-norma kemasyarakatan agar masyarakat kita perlu belajar untuk menghargai hakhak perempuan.

Salah satu hal yang menarik konsep dari aborsi ini adalah pandangan salah satu tokoh mufassir Indonesia, Quraish Shihab, beliau mempunyai pandangan yang unik tentang aborsi, pernyataan bahwa aborsi dapat dilakukan apabila ada pertimbangan kuat dari pakar kedokteran dalam bidang ini, dapat menggugurkan dan 
memperbolehkan aborsi tanpa ada batasan apapun. Pemikiran ini dapat kita cari dasar argument secara ushuliyyah dan kaidah fiqbiyyah. Dinamisasi hukum Islam yang diajarkan oleh Quraish Shihab ini menjadi menarik dikaji dan dilacak akar pemikiran dan bagaimana epistemologi hukum Islam yang dibangunnya.

\section{Temuan Penelitian dan}

\section{Pembahasan}

1. Biografi Singkat M. Quraish

Shihab

M. Quraish Shihab dilahirkan pada 16 Februari di kabupaten Sidenreng Rappang, Sulawesi Selatan, sekitar $190 \mathrm{KM}$ dari kota Ujung Pandang. ${ }^{6}$ Ia berasal dari keturunan Arab yang terpelajar.

${ }^{6}$ M. Quraish Shihab, Membumikan AlQur'an; Fungsi dan Peran Wabyu dalam Kebidupan Maysarakat (Bandung; Mizan, 2004), 6 dan Saiful Amin Ghafur, Profil Para Mufassir Al-Qur'an, (Yogyakarta: Pustaka Insan Madani, 2008), 236.
Quraish Shihab merupakan nama keluarganya (ayahnya) seperti lazimnya yang digunakan di wilayah Timur (anak benua India termasuk Indonesia).

Quraish Shihab dibesarkan dalam lingkungan keluarga Muslim yang taat, pada usia 9 tahun, ia sudah terbiasa mengikuti ayahnya ketika mengajar. Ayahnya, Abdurrahman Shihab (1905-1986) merupakan sosok yang banyak membentuk kepribadian bahkan keilmuannya kelak. Menamatkan pendidikannya di Jammiyah alKhair Jakarta, yaitu sebuah lembaga pendidikan Islam tertua di Indonesia. Ayahnya seorang guru besar di bidang Tafsir dan pernah menjabat sebagai rektor IAIN Alaudin Ujung Pandang dan juga sebagai pendiri 


\section{Uzlah Wahidah Maulidiyah}

Universitas Muslim Indonesia (UMI) Ujung Pandang. ${ }^{7}$

Menurut Quraish Shihab, sejak 6-7 Tahun, ia sudah diharuskan untuk mendengar ayahnya mengajar Al-Quran. Dalam kondisi seperti itu, kecintaan seorang ayah terhadap ilmu yang merupakan sumber motivasi bagi dirinya terhadap studi $\mathrm{Al}$ Quran. ${ }^{8}$ Di samping ayahnya, peran seorang Ibu juga tidak kalah pentingnya dalam memberikan dorongan kepada anak-anaknya untuk giat belajar terutama masalah agama. Dorongan sang Ibu inilah yang menjadi motivasi ketekunan dalam menuntut ilmu agama sampai membentuk kepribadiaanya yang kuat terhadap basik keislaman.

Dengan melihat latar belakang keluarga yang sangat kuat dan disiplin, maka sangat wajar jika kepribadian, keagamaan, dan kecintaan serta minat terhadap

${ }^{7}$ Alwi Shihab, Islam Inklusif: Menuju Terbuka dalam beragama (Bandung: Mizan,1999), V.

${ }^{8}$ Saiful Amin Ghafur, Profil Para Mufassir Al-Qur'an, 237. ilmu-ilmu agama dan studi AlQuran yang digeluti oleh Quraish Shihab sejak kecil hingga kemudian didukung latar belakang pendidikan yang dilaluinya mengantarkannya menjadi seorang muffasir handal.

Quraish Shihab memulai pendidikannya di kampung halamannya di Ujung Pandang, dan melanjutkan pendidikan menengahnya di Malang, tepatnya di Pondok Pesantren Dar al-Hadis alFiqhiyyah. ' Kemudian pada tahun 1958, dia berangkat ke Kairo Mesir untuk meneruskan pendidikannya di al-Azhar dan diterima di kelas II Tsanawiyyah. Selanjutnya pada Tahun 1967 dia meraih gelar Lc (S1) pada Fakultas Ushuluddin Jurusan Tafsir Hadis Universitas Al-Azhar. Kemudian dia melanjutkan pendidikanya di fakultas yang sama, sehingga tahun 1969 ia meraih gelar MA untuk sepesialis tafsir Al-Quran

${ }^{9}$ Quraish Shihab, Membumikan alQur'an, 14. 
Vol. 12, No. 2, Oktober 2019

p-ISSN:2086 -0749

e-ISSN:2654-4784

dengan judul Al-Ijaz al-Tasri' Li AlQur'an Al-Karim. ${ }^{10}$

Pada tahun 1980, Quraish Shihab kembali melanjutkan pendidikanya di Universitas Al-Azhar, dan menulis disertasi yang berjudul Nazm Al-Durar Li Al-Biqa'iy, Tahqiq wa Dirasah sehingga pada tahun 1982 berhasi meraih gelar doktor dalam studi ilmu-ilmu Al-Quran dengan yudisium Summa Cumlaude, yang disertai dengan penghargaan tingkat 1 (Mumtaz Ma'a Martabat alSyaraf al-Ula). Dengan demikian ia tercatat sebagai orang pertama dari Asia Tenggara yang meraih gelar tersebut. $^{11}$

Setelah kembali ke Indonesia, pada tahun 1984, Quraish Shihab ditugaskan di fakultas Ushuluddin dan Program Pasca Sarjana IAIN Syarif Hidayatullah Jakarta. Pada

\footnotetext{
${ }^{10}$ Quraish Shihab, Membumikan AlQur'an, 6.

${ }^{11}$ Quraish Shihab, Memmbumikan AlQur'an, 5.
}

tahun 1995, ia dipercaya menjabat Rektor IAIN Syarif Hidayatullah Jakarta. Jabatan tersebut memberikan peluang untuk merealisasikan gagasan-gagasanya, salah satunya diantaranya melakukan penafsiran dengan menggunakan pendekatan multidisipliner, yaitu pendekatan yang melibatkan sejumlah ilmuwan dari berbagai bidang spesialisasi. Menurutnya, hal ini akan lebih berhasil untuk mengungkapkan petunjuk-petunjuk dari Al-Quran secara maksimal. ${ }^{12}$ Jabatan lain di luar kampus yang pernah diembannya, antara lain, Ketua Majlis Ulama Indonesia (MUI) Pusat sejak 1984, anggota Lajnah Pentashih Al-Quran Departemen Agama sejak 1989, selain itu ia banyak berkecimpung dalam berbagai organisasi professional,

\footnotetext{
${ }^{12}$ Kasmantoni, Lafadz. Kalam dalam Tafsir al-Misbah Quraish Shibab Studi Analisa Semantik (Yogyakarta: UIN Sunan Kalijaga, Tesis 2008), 31.
} 


\section{Uzlah Wahidah Maulidiyah}

seperti pengurus perhimpunan ilmu-ilmu Al-Quran, Pengurus Konsorsium Ilmu-Ilmu Agama Departemen Pendidikan dan Kebudayaan, dan Asisten Ketua Umum Ikatan Cendekiawan Mus$\lim$ Indonesia (ICMI), ${ }^{13}$ serta Direktur Pendidikan Kader Ulama (PKU) yang merupakan usaha MUI untuk membina kader-kader ulama di tanah air. ${ }^{14}$

Pada tahun 1998, tepatnya di akhir pemerintahan Orde Baru, ia pernah dipercaya sebagai Menteri Agama oleh Presiden Suharto, kemudian pada 17 Februari 1999, dia mendapat amanah sebagai Duta Besar Indonesia di Mesir. Walaupun berbagai kesibukan sebagai konsekwensi jabatan yang diembannya, Quraish Shihab tetap aktif dalam kegiatan tulis menulis di berbagai media massa dalam rangka menjawab permasalahan yang

\footnotetext{
13 Quraish Shihab, Membumikan AlQur'an, 6.

14 Quraish Shihab, "Menyatukan Kembali al-Qur'an dan Umat" dalam jurnal Ulumul Qur'an, Vol. V, No, 3, 1993, 13.
}

berkaitan dengan persoalan agama. ${ }^{15}$ Di harian Pelita, ia mengasuh rubrik "Tafsir Amanab" dan juga menjadi anggota dewan Redaksi majalah Ulum al-Qur'an dan Mimbar Ulama di Jakarta. Kini, aktifitasnya adalah Guru Besar Pasca Sarjana UIN Syarif Hidayatullah Jakarta dan Direktur Pusat Studi al-Qur'an (PSQ) Jakarta. ${ }^{16}$

Sebagai mufassir kontemporer dan penulis yang produktif, Quraish Shihab telah menghasilkan berbagai karya yang telah banyak diterbitkan dan dipublikasikan. ${ }^{17}$ Diantara karya-karyanya adalah:

a. Tafsir Al-Manar: Keistimewaan dan Kelemahannya, tahun 1984 diterbitkan di IAIN Alauddin Ujung Pandang.

b. Filsafat Hukum Islam, tahun 1987 diterbitkan di Jakarta (Departemen Agama RI).

15 Saiful Amin Ghafur, Profil Para Mufassir, 238.

16 M. Quraish Shihab, Mu'jizat alQur'an ditinjau Dari Aspek Kebabasaan, Isyarat Ilmiyyah dan Pemberitaan Ghaib (Jakarta: Mizan, 2007), 297.

${ }^{17}$ Kasmantoni, Lafaz Kalam, 32-37. 
An-Nisa' : Jurnal Kajian Perempuan \& Keislaman

Vol. 12, No. 2, Oktober 2019

p-ISSN:2086-0749

e-ISSN:2654-4784

c. Mabkota Tuntunan Illabi : Tafsir

Surat Al-Fatihah, tahun 1988

diterbitkan di Jakarta (Untaga-

ma).

d. Membumikan Al-Qur'an: Fungsi

dan Peranan Wabyu dalam Ke-

bidupan Maysarakat, tahun 1994

diterbitkan di Bandung (Mi-

zan).

e. Studi Kritik Tafsir al-Manar,

1994, diterbitkan di Bandung

(Pustaka Hidayah).

f. Lentera Hati: Kisah dan Hikmah

Kehidupan, tahun 1994, diterbit-

kan di Bandung (Mizan).

g. Untaian Permata buat Anakku:

Pesan al-Qur'an untuk. Mempelai,

tahun 1995 diterbitkan di Ban-

dung (Mizan).

h. Wawasan al-Qur'an: Tafsir

Maudhu'i atas berbagai persoalan

Umat, tahun 1996 diterbitkan

di Bandung (Mizan). i. Hidangan Ayat-Ayat Tablil, tahun 1997, diterbitkan di Jakarta (Lentera Hati).

j. Tafsir al-Qur'an Al-Karim: Tafsir Surat-surat Pendek Berdasarkan Urutan Turunya Wabyu, tahun 1997, diterbitkan di Bandung (Pustaka Hidayah).

k. Tafsir al-Misbah, Pesan, Kesan dan Keserasian Al-Qur'an, tahun 2001, diterbitkan di Jakarta (Lentera Hati). dan lain sebagainya.

Berbagai karya yang telah disebutkan di atas, menandakan bahwa peranannya dalam perkembangan keilmuan di Indonesia khususnya dalam bidang Al-Quran. Dari sekian banyak karyanya, Tafsir Al-Misbab: Pesan, Kesan dan Keserasian Al-Qur'an merupakan maha karyanya. Melalui tafsir inilah namanya melambung sebagai salah satu muffasir Indonesia, yang mampu menu- 


\section{Uzlah Wahidah Maulidiyah}

lis tafsir Al-Quran 30 Juz dari Volume 1 sampai 15.

Dalam tulisan ini penulis mencoba melakukan kajian ulang pemikiran dan mencoba menelusuri landasan hukum dan metodologi hukum yang digunakan oleh Quraish Shihab dalam mengkaji hak reproduksi bagi perempuan yang berkaitan dengan aborsi.

2. Pandangan Quraish Shihab

Mengenai Aborsi

Menurut Quraish Shihab, aborsi adalah pengguguran kandungan (janin) sebelum sempurna masa kehamilan -baik dalam keadaan hidup ataupun tidak- sehingga keluar dari rahim dan tidak hidup, baik itu dilakukan oleh obat ataupun selainnya, oleh yang mengandungnya maupun oleh orang lain. Salah satu sebab terjadinya aborsi menurut Quraish Shihab adalah adanya pergaulan bebas yang sering diistilahkan dengan kecelakaan, ${ }^{18}$ yang sering

${ }^{18}$ M. Quraish Shihab, Perempuan: Dari Cinta sampai Seks dan Nikah Mut'ah dari disebut dengan hamil tanpa didahului dengan akad nikah secara sah. Yang jelas proses kehamilan ini tidak dikehendaki karena takut menanggung aib. Dan juga ada problem lain serupa, seperti belum siap untuk memikul beban perekonomian yang lebih karena masih belum mapan secara ekonomi. ${ }^{19}$

Dalam beberapa kajian telah dipaparkan adanya pembicaraan berkenaan dengan aborsi. Ulama sejak awal sudah membuat acuanacuan strategis dalam masalah aborsi, kalangan ulama madzhab juga memberikan ruang yang lebih dalam mengkaji tentang aborsi, walupun pikiran dan telaah mereka mempunyai ruang dan waktu yang menjadi pra kondisi para ulama madzhab dalam menggali pan-

Bias Lama sampai Bias Baru (Jakarta: Lentera Hati, 2005), 257.

${ }^{19}$ Diperkirakan bahwa ada sekitar tiga juta perempuan Indonesia yang melakukan aborsi setiap tahunnya, dan hampir $20 \%$ adalah para remaja, sedangkan sisanya adalah perempuan yang sudah berkelurga, terhimpitnya kehidupan ekomoni menjadi salah satu faktor utama untuk tidak memiliki anak terlebih dahulu. 
dangan mereka tentang konsep aborsi.

Dalam beberapa madzhab, misalnya dalam pandangan Abu Hanifah, pendiri madzhab Hanafi (w.150), aborsi diperbolehkan sebelum masa kandungan melebihi empat bulan dari usia masa kandungan, dalam hal ini menurut Quraish Shihab, aborsi boleh atas izin suami maupun tidak meminta izin. Kondisi pembolehan menurut Abu Hanifah tidak murni pembolehan secara mutlak, akan tetapi mempunyai kondisi dan mental yang mendukung untuk melakukan aborsi, diperbolehkan aborsi apabila ditemukan dalam keluarga yang akan melakukan aborsi, pertama, dimungkinkan sang ibu tidak mampu memenuhi kebutuhan air susu bagi si bayi, kedua, adanya ekonomi yang lemah apabila mengandung dalam waktu dekat, kondisi ini menjadi pertimbangan diperbolehkan aborsi dalam pandangan ulama kalangan Hanafi. ${ }^{20}$

\begin{abstract}
${ }^{20}$ M. Quraish Shihab, Perempuan, 259. Yang menarik adalah pendapat dari kalangan ulama Hanafiyyah kontemporer, salah satu tokoh ulama ini adalah AlButhi, bahwa memperbolehkan aborsi sebelum kehamilan memasuki bulan keempat hanya dalam tiga kasus yaitu: pertama, apabila dokter khawatir bahwa kehidupan ibu terancam akibat kehamilan. Kedua, jika kehamilan dikhawatirkan akan menimbulkan penyakit di tubuh Ibunya. Ketiga, apabila kehamilan yang baru dapat menyebabkan terhentinya proses menyusui bayi yang sudah ada dan kehidupan sangat bergantung pada susu ibunya, Muhammad Said al Buthi, Tahdid al-Nass (Damaskus: Maktabah al-Farabi, 1979), 179. Yang menjadi dasar diperbolehkan pengguguran pada setiap tahap sebelum terjadinya pemberian nyawa bahwa setiap sesuatu yang belum diberikan nyawa tidak akan dibangkitkan di hari kiamat. Begitu pula dengan janin yang belum diberikan nyawa, maka ketika tidak ada larangan baginya, maka boleh digugurkan. Indikasi lain yang sering dikutip dalam madzhab ini adalah ketika si ibu pada waktu hamil sedang dalam keadaan kondisi menyusui anaknya dan susunya terhenti, sementara si ayah tidak mempunyai biaya untuk menyediakan susu pengganti, keadaan ini dibenarkan untuk memelihara kehidupan si anak yang sedang menyusui, sementara alasan lain juga biasanya ketika terjadi sesuatu yang buruk menimpa si ibu, seperti adanya resiko dalam melahirkan. Maria Ulfa Anshor, Fikih Aborsi, 95.
\end{abstract}




\section{Uzlah Wahidah Maulidiyah}

Sedangkan pandangan ulama madzhab yang berseberangan dengan Hanafi, misalnya Maliki, sangat keras melarang aborsi, bahkan sperma yang baru bertemu ovum pun juga dilarang dikeluarkan, walaupun masanya kurang dari empat puluh hari. ${ }^{21}$ Sedangkan dalam pandangan madzhab Hanbali boleh menggugurkan kandungan sebelum empat bulan dengan menggunakan obat yang dapat dibenarkan. 22

Yang menarik adalah pandangan ulama Syafi'iyyah. Terjadi pergulatan perbedaan pendapat tentang boleh tidaknya menggugurkan kandungan ketika adanya pertemuan sperma dan ovum, tetapi mereka sepakat tentang haramnya

${ }^{21}$ M. Quraish Shihab, Perempuan, 259.

${ }^{22}$ M. Quraish Shihab, Perempuan, 260. Pembahasan lebih mendalam diungkapkan oleh Maria Ulfa, bahwa menurut Jumhur Ulama Hanabilah, janin boleh digugurkan selama masih dalam fase segumpal darah (mudghah) karean belum berbentuk anak manusia, sebagaimana ditegaskan oleh Ibnu Qudamah dalam kitab al-Mugni, Penguguran janin yang masih berbentuk mudghab dikenai denda, bila menurut tim spesialis kandungan janin sudah terlihat bentuknya. aborsi setelah masa empat bulan. ${ }^{23}$ Ulama juga sepakat bahwa bagi pelaku aborsi akan mendapatkan dosa dan sekaligus membayar diyat, yaitu denda seperduapuluh dari diyat pembunuhan atau senilainya. ${ }^{24}$

Ketentuan dilarangnya aborsi menurut beberapa ulama yang dikutip oleh Quraish Shihab adalah beberapa ayat Al-Quran, landasan yang dipakai adalah ayat QS. AlTakwir dalam ayat itu menggunakan berbagai perumpamaanperumpamaan. Dalam perempuaan itu semisal tergulung/kehancuran matahari. Berjatuh-jatuhnya bintang, dan dihancurkannya gununggunung. Bersamaan dengan ayat tersebut, ayat selanjutnya menyatakan "karena dosa apakah (ia) anak perempuan dibunuh/atau dikubur hidup-hidup. Jika merujuk AlQuran, Al-Quran mempunyai tiga alasan terpenting yang menjadi motivasi para pelaku aborsi. Pertama, khawatir jatuhnya orang tua

\footnotetext{
${ }^{23}$ M. Quraish Shihab, Perempuan, 260.

${ }^{24}$ M.Quraish Shihab, Perempuan, 260.
} 
Vol. 12, No. 2, Oktober 2019

p-ISSN:2086 -0749

e-ISSN:2654-4784

pada lembah kemiskinan dengan menanggung biaya hidup anak-anak perempuan yang lahir (baca QS. AlAn'am (6): 151). Kedua, khawatir menanggung jatuhnya anak dalam lembah kemiskinan jika mereka dewasa kelak (baca surat QS. Al-Isra' (17) : 31). Ketiga, khawatir menanggung aib akibat ditawan dalam peperangan sehingga diperkosa akibat perzinaan. ${ }^{25}$

Quraish Shibab mencoba mencermati realitas yang ada di masyarakat, apabila kejadian aborsi adalah murni kejadian "kecelakaan" diakibatkan kecerobohan manusia, dengan melakukan hubungan di luar nikah, hal tersebut pantas mendapatkan dosa besar. Tetapi apabila melihat realitas ternyata berbeda, alasan aborsi adalah karena dimungkinkan adanya cacat yang diakibatkan bila anak itu lahir, dan kemungkitan kecacatan itu sudah

${ }^{25}$ M. Quraish Shihab, Perempuan, 263. diprediksi oleh dokter yang memang benar-benar pakar dalam bidangnya, sebagaimana yang telah diperbincangkan antara Quraish Shihab dengan seorang mufti Mesir, yaitu Syaikh Muhammad Thanthawi, menyangkut kasus semacam in, beliau dengan sangat-sangat hatihati menjawab, jika memang dokter yang terpercaya menilai bahwa kualitas hidup janin itu setelah kelahiran akan sangat rendah akibat cacat bawaan atau penyakit yang diidap, aturan legal aborsi dapat dipertimbangkan, dan dalam mengungkapkan hal ini usia janin bukan menjadi persoalan. Jika demikian apabila usia janin melebihi atau kurang dari empat bulan dan kondisi yang mengkhawatirkan sebagaimana yang telah beliau ungkapkan, maka kelegalan aborsi dapat dipertimbangkan. ${ }^{26}$

3. Maslahat Sebagai Pandangan

${ }^{26}$ M. Quraish Shihab, Perempuan, 261. 


\section{Uzlah Wahidah Maulidiyah}

Teori mashlahat dan maqashid menjadi sangat relevan sehingga menjadi penting untuk dikaji dalam tulisan ini. Al-Syatibi mengklasifikasikan tujuan Hukum al-Maqashid al-Syariah sebagai berikut:

a. Maksud awal syari' dalam
penetapan hukum.
Dalam pasal ini dibahas tentang kemashlahatan manusia. AlSyatibi membagi kemashlahatan menjadi tiga bagian: dharuriyyah, bajizyyah dan tahsiniyyah. ${ }^{27}$ Dalam tataran ini dharuriyyah adalah kepentingan agama dan dunia yang mana tanpa kehadirannya akan menimbulkan kerusakan dan cacat di dunia dan di akhirat. Sedangkan yang dimaksud dengan bajiyyah adalah kepentingan sekunder yang berupa kepentingan-kepentingan yang dibutuhkan untuk menghilangkan kesukarankesukaran dalam kehidupan mukallaf dan memberikan keleluasaan.

\footnotetext{
${ }^{27}$ Secara sederhana bisa diterjemahkan dalam kepentingan primer sekunder dan tersier.
}

Sedangkan dalam tahsiniyyah adalah kepentingan pelengkap yang berarti mengambil yang sesuai dengan apa yang terbaik dari sebuah kebiasaan dan menghindari cara-cara yang tidak disukai oleh orang-orang bijak. $^{28}$

Dalam masalah dharuriyyah ada lima hal yang dikedepankan, yaitu agama, jiwa, keturunan, nafs, harta dan intelektual. Kelima kategori ini menurut ulama dan menurut Al-Syatibi adalah universal. Kewajiban hukum syar'i dapat dibagi menjadi aspek positif dan cara-cara protektif preventif. Aspek positifnya adalah ibadah dan muamalah, sedangkan aspek preventifnya adalah adanya hukuman qishas, jinayah dan lain-lain. ${ }^{29}$ Kepentingan primer adalah landasan dari kepentingan sekunder

\footnotetext{
${ }^{28} \mathrm{Al}-\mathrm{Syatibi,}$ Al-Muwafaqat fi al-Ushul al-Syariah (Beirut: Dar al-Kutub alIlmiah, t t), 7.

${ }^{29}$ Pandangan baru penulis adalah tentang perlindungan agama bukan saja agama Islam, tapi agama lain juga harus dilindungi, sehingga toleransi umat beragama akan berjalan secara seimbang dan membawa mashlahat dalam kehidupan yang nyata.
} 
Vol. 12, No. 2, Oktober 2019

p-ISSN:2086 -0749

e-ISSN:2654-4784

dan kepentingan tersier, syarat-syarat sebagai unsur

sebagaimana kepentingan

pelengkap sebagai unsur kepentingan sekunder.

Ketiga tingkatan tersebut, kata Al-Syatibi membuat struktur yang saling berhubungan. Dia menganalisa ada dua aspek dalam hubungan yang satu dengan yang lainnya. Pertama, setiap tingkatan secara terpisah menuntut adanya unsur pelengkap. Kedua, masingmasing terkait dengan yang lainnya. Misalnya qishas mempersyaratkan sebagai pelengkap adalah tasammul, evaluasi paralel. Namun demikian, ketertiban struktur ini melahirkan satu kaidah penting sebagai satu kaidah prioritas dalam mentarjih hal-hal yang bertentangan, yaitu pertimbangan unsur pelengkap tidak boleh membatalkan tujuantujuan asal primer. ${ }^{30}$ Misalnya dalam hal ini adalah shalat. Shalat memiliki

${ }^{30}$ Al-Syatibi, Al-Muwafaqat, 11. pelengkap seperti bersuci, menghadap qiblat dan lain-lain. Apabila pemenuhan syarat-syarat ini berakibat menegasikan unsur-unsur primer dengan meninggalkan shalat misalnya maka syarat-syarat itu harus dikesampingkan. ${ }^{31}$

Hubungan yang terjadi antara tiga tingkatan tadi adalah sama dengan hubungan kepentingan pelengkap dengan tujuan asal hukum. Jadi kepentingan pelengkap merupakan unsur penyempurna bagi kepentingan sekunder. Sedangkan kepentingan sekunder menjadi pelengkap dan penopang kepentingan primer. Dengan landasan tersebut Al-Syatibi dapat merumuskan lima ketentuan, pertama, kepentingan primer merupakan asal dan dasar dari kepentingan lain. Kedua, kerusakan kepentingan primer adalah kerusakan pada

${ }^{31} \mathrm{Al}$-Syatibi, Al-Munafaqat,12. 


\section{Uzlah Wahidah Maulidiyah}

kepentingan yang lain dalam level mutlak. Ketiga, sebaliknya kerusakan kepentingan yang lain tidak harus berarti merusak kepentingan primer. Keempat, dalam kasus tertentu kerusakan pada kepentingan pelengkap bisa berakibat rusaknya kepentingan primer. Dan kelima, perlindungan atas kepentingan sekunder dan pelengkap harus dilakukan untuk mencapai kepentingan primer.

b. Maksud syar'i dalam melembagakan hukum agar bisa dipahami.

Aspek ini merupakan pembahasan yang ringkas karena hanya terdiri dari lima masalah yang pada intinya bisa dikembalikan dalam dua masalah besar, pertama, adalah syari'ah ini berbahasa Arab. ${ }^{32}$ Kedua, bahwa ketentuan-ketentuan syari'ah itu ummiyah. ${ }^{33}$ Hubungan antara kedua pembahasan ini adalah bahwa keduanya adalah pintu masuk yang digunakan untuk

${ }^{32} \mathrm{Al}$-Syatibi, Al-Muwafaqat, 49.

${ }^{33} \mathrm{Al}-\mathrm{Syatibi,} \mathrm{Al-Muwafaqat,} 53$. mengetahui tujuan-tujuan hukum. Dan karena Al-Quran adalah berbahasa Arab hendaknya manusia yang ingin mengetahui tentang tujuan hukum harus menguasai bahasa Arab.

Al-Syatibi juga menyatakan bahwa kenapa harus ummiyah karena orang Arab juga ummiyah. Ummi dalam pandangan orang Arab bahwa orang Arab tidak mengetahui pandangan tentang pengetahuan kuno Yunani misalnya. Walaupun demikian ketika melakukan ijtihad perlu menggandeng orang-orang yang mahir dalam bidang segala ilmu (Ijtibad Jama'i). Pertimbangan ini melihat bahwa tidak benar seseorang menuntut lebih dari apa yang dipahami oleh orang-orang ummi. Pertimbangan ini juga akan menuntut bahwa kewajiban maupun perbuatan harus dalam kapasitas intelektual seorang ummi. Dan ketika sebuah kapasitas itu diterapkan kepada yang bukan kaumnya hal itu tidak adil, misalnya dalam hal 
Vol. 12, No. 2, Oktober 2019

p-ISSN:2086 -0749

e-ISSN:2654-4784

shalat bagi kalangan umum menggunakan kriteria yang bersifat praktis berupa terbit dan terbenamnya matahari dari pada astronomi walaupun astronomi juga harus dipelajari oleh orang yang mampu.

c. Tujuan syar'i dalam melem-

bagakan hukum sebagai

beban kewajiban.

Dalam aspek ini Al-Syatibi menyatakan bahwa tujuan hukum adalah taklif sedangkan batas-batas wilayah taklif adalah yang dimaksudkan dan yang tidak. Ada dua pembahasan dalam wilayah ini, pertama, adalah taklif dalam sesuatu yang tidak pernah mungkin dapat dilakukan. Kedua, taklif yang ditetapkan pada sesuatu yang mengandung kesulitan. Unsur yang pertama sangat mustahil dapat ditemukan dalam syari'ah, karena pada dasamya taklif itu selalu mempersyaratkan kemampuan mukallaf dalam melaksankannya.
Bilamana ada taklif yang ada di luar kemampuan manusia maka hal itu hakekatnya merupakan perintah dengan sebab-sebab yang mendahului atau akibat-akibat yang menyertainya.

Syar'i juga tidak menghendaki masyaqqah, kesulitan yang timbul akibat dari taklif. Ada banyak sekali hujjah yang menjadi landasan pendapat ini dalam Al-Quran dan hadis secara eksplisit menegasikan maksud syar'i untuk memaksakan suatu kesulitan. Adanya rukshah yang dikenalkan dalam syara' adalah bukti adanya konsesi untuk menyingkirkan kesulitan.dan ijma' juga menetapkan bahwa syar'i sama sekali tidak bermaksud menjadikan perbuatan-perbuatan yang sulit menjadi sebuah kewajiban. Walaupun demikian bahwa sebuah kewajiban itupun juga tidak akan terlepas dari kesulitan-kesulitan. Dan kesulitan-kesulitan dalam se- 


\section{Uzlah Wahidah Maulidiyah}

buah kewajiban itu ada dua, pertama, idbtirari, adalah kesulitan yang merupakan kosenkuensi logis dan tidak bisa dihindari dari suatu perbuatan tertentu. Kedua, adalah khariji, kesulitan yang menimpa mukallaf tanpa memiliki hubungan apapun dengan kewajiban.

Kesulitan yang bersifat inheren adalah kesulitan yang pertama karena kesulitan ini adalah yang disebabkan oleh seseorang dalam memenuhi dan mencukupi kebutuhan hidupnya. Begitu pula kewajiban mesti mengandung suatu kesulitan, hanya saja kesulitan itu lumrah dan wajar. Sedangkan kesulitan yang bersifat khariji adalah kesulitan yang bukan akibat dari perbuatannya, akan tetapi dia bisa berpengaruh terhadap kewajiban tersebut. Tujuan syari' bukan kesulitan akan tetapi kemashlahatan bagi mukallaf, yang terdapat dalam kewajiban. Dari sini akan muncul sebuah kaidah bahwa kesulitan tidak boleh menjadi tujuan mukallaf untuk mendapatkan pahala yang besar. Alasanya karena, pertama, bahwa kriteria pahala itu itu terletak pada perbuatan bukan pada kesulitan. Kedua, bahwa ada ketentuan perbuatan itu tergantung pada niat, maka dari itu niat mukallaf harus selaras dengan niat syar'i. dan karena syar'i tidak menghendaki kesulitan, maka mencari kesulitan dalam hal ini berarti melanggar maksud syar'i. Pelanggaran ini tidak bisa mendatangkan pahala.

Syar'i menginginkan kemudahan menurut Al-Syatibi karena ada dua hal yang ingin dituju, supaya tidak bosan dan benci kepada ibadah dan menjaga keseimbangan dalam memenuhi tugas-tugas kewajiban secara keseluruhan. Intinya adalah mukallaf dapat melaksanakan semua kewajiban secara berkelanjutan tanpa mementingkan yang satu dengan meninggalkan yang lain, sebab syari'ah memiliki sifat dasar yang moderat tidak ekstrim. 
Vol. 12, No. 2, Oktober 2019

p-ISSN:2086 -0749

e-ISSN:2654-4784

d. Tujuan syar'i adalah

memasukkan mukallaf di

bawah perintah taklif.

Al-Syatibi memberikan porsi yang sangat besar dalam berbagai persoalan yang menyangkut masalah ini, karena persoalan ini hampir menyamai tiga macam tujuan syar'i yang pertama. Hal ini dapat dilihat dalam bab masalah yang kesembilan sampai ke enam belas. Sungguhpun demikian, poin terpenting dalam pembahasan ini adalah tujuan syar'i memasukkan mukallaf dalam kewajiban hukum syari'ah bahwa bagaimanapun semuanya harus patuh kepada hukum-hukum syari'ah. ${ }^{34}$

Adapun tujuannya adalah mengeluarkan mukallaf dari dorongan (semata-mata) hawa nafsunya sehingga ia bisa menjadi hamba Allah secara sukarela, sebagaimana dia hamba Allah

${ }^{34}$ Al-Syatibi, Al-Muwafaqat, 168. secara pasti. Untuk membuktikan poin itu Al-Syatibi mengungkapkan argumen dari Al-Quran dan Sunnah dimana mengikuti hawa Nafsu secara meyakinkan dicela. Dia berpendapat bahwa pengalaman manusia dalam masyarakat menceritakan pada kita bahwa mashalih, baik mengenai masalah keagamaan duniawi, tidak bisa dicapai dengan cara mengikuti hawa nafsu dan motif-motif egois, syari'ah menurut $\mathrm{Al}$ Syatibi, bermaksud mencapai mashlahah bukan merealisasi hawa nafsu. ${ }^{35}$

Dari pembahasan di atas ada satu kaidah besar yang dapat dihasilkan "bahwa setiap amal yang dituntun oleh hawa nafsu, tanpa memperhatikan perintah (amar), larangan (nabi), serta pilihan syar'i secara mutlak batal“. Jika ada percampuran maka dipilih yang palig dominan sebagai penetapan

${ }^{35}$ Al-Syatibi, Al-Muwafaqat, 128. 


\section{Uzlah Wahidah Maulidiyah}

hukumnya, hal ini dilandasi "karena sekalipun mengikuti hawa nafsu merupakan jalan menuju perbuatan tercela sekalipun berada dalam perbuatan yang terpuji". ${ }^{36}$

Kalau sebuah perbuatan sudah mencapai tujuan syar'i maka kesesuaiannya ada dua kemungkinan, apakah mengikuti tujuan asal (maqashid ashliyah), ataukah tujuan sekunder (maqashid tabiah), yang dimaksud dengan tujuan utama adalah tidak memberi tempat bagi keuntungan pribadi mukallaf. Yang termasuk dalam tujuan asal adalah kelompok atau kewajiban-kewajiban yang bersifat universal yang terdiri dari lima kepentingan masalah yang dharuri. Tujuan asal ini tidak memberi tempat bagi keuntungan pribadi mukallaf karena ia harus memelihara eksistensinya, suka atau tidak suka. Hal ini adalah usaha memelihara lima prinsip universal

36Al-Syatibi, Al-Muwafaqat, 132. yang tidak bergantung atas kemauan mukallaf. ${ }^{37}$

Sedangkan dengan tujuan sekunder adalah tujuan yang menyediakan keuntungan pribadi bagi mukallaf, dari arah ini mukallaf bisa menentukan tuntutan alamiah (syahwat) dan kesenangan yang juga dimaksudkan untuk dipuaskan. AlSyatibi mempunyai argumen dalam memahami mekanisme ini, menurut dia tujuan yang ada kaitannya dengan masalah pribadi adalah tujuan berbasis maqashid tabiah, sedangkan yang berbasis asal adalah maqashid ashliyah. Dan jika tujuan ashliyah sebagai tujuan pertama dan itu juga ada kepentingan pribadi maka tujuan tabiah-nya menempati pada posisi yang kedua.

Sebagaimana contoh adalah dalam tujuan universal untuk menegakkan kehidupan dengan bifzh al-nasl adalah tujuan ashliyah, sedangkan tujuan tabiah-nya makan makanan yang enak, memakai pakaian yang bagus, memiliki

${ }^{37}$ Al-Syatibi, Al-Muwafaqat,149. 
Vol. 12, No. 2, Oktober 2019

p-ISSN:2086 -0749

e-ISSN:2654-4784

kendaraan yang baik, menikahi istri yang cantik. Itu termasuk dalam kategori memelihara kehidupan yang tergolong tujuan tabi'ab. ${ }^{38}$

Dalam konteks aborsi ini, M. Quraish Shihab mencoba memberikan pandangan dengan berpegang pada mashlabat dan maqashid al-syari'ah ala Al-Syatibi. Aborsi boleh dilakukan apabila ada beberapa persyaratan yang telah disebutkan sebagai bentuk ukuran kebolehan dalam melakukan aborsi, tinjauan ini mengambarkan bahwa hifžb al-din di utamakan dari pada hif:̧ al-nasl yang secara hierarki hukum, menjaga agama dengan menjaga sang ibu agar selamat itu lebih baik dari pada meneruskan kehamilan sang ibu yang secara keilmuan medis akan berakibat bagi keduanya.

${ }^{38}$ Al-Syatibi, Al-Munafaqat ,153.

\section{Simpulan}

Dalam tulisan ini secara ringkas penulis menjelaskan bagaimana konsep aborsi, telaah hukum Islam, dan pandangan Quraish Shihab. Ada beberapa pandangan Quraish Shihab yang unik, pertama, dia mencoba meletakkan posisi aborsi yang menurutnya "tidak boleh" adalah aborsi yang terlahir dari "kecelakaan prilaku" berupa pergaulan bebas, kedua, bahwa apabila aborsi itu dilakukan harus mengindahkan keilmuan lain terutama medis. Dalam melihat "kebolehan" terhadap adanya aborsi pada keluarga tersebut, misalnya untuk menyelamatkan sang ibu, apabila tetap mempertahankan kandungan si anak dengan kondisi apabila kandungan membahayakan si ibu, dan tidak dimungkinkan adanya kehidupan bagi si anak apabila kandungan itu tetap 


\section{Uzlah Wahidah Maulidiyah}

dipertahankan atau apabila anak yang di kandungnya lahir akan membawa indikasi penyakit dan cacat yang membahayakan sang ibu.

Beberapa pertimbangan ini menjadi titik poin penting atas "kebolehan" aborsi. Dalam kajian hukum Islam, Quraish Shihab menggunakan konteks mashlahat dan maqashid al-syar'iah sebagai lan-dasan berfikir.

\section{Daftar Pustaka}

Al-Suyuti, Jalaludin, Al-Itqan fi Ulum al-Qur'an (Kairo: tt, th).

Al-Syatibi, Imam, Al-Munvaffaqat fi al-Ushul al-Syari'ah (Beirut: Dar al-Kutub al-Ilmiah, t t.

Ghafur, Saiful Amin, Profil Para Mufassir Al-Qur'an (Yogyakarta: Pustaka Insan Madani, 2008).

Kasmantoni, Lafadz Kalam dalam Tafsir al-Misbah Quraish Shibab Studi Analisa Semantik (Yogyakarta: UIN Sunan Kalijaga Tesis 2008).
Shihab, Alwi, Islam Inklusif: Menuju Terbuka dalam Beragama (Bandung: Mizan,1999).

Shihab, M. Quraish, Esklikopedia Al-Qur'an: Kajian Kosa kata. (Jakarta: Lentera Hati, 2007) , Mukjizat al-Qur'an, ditinjau dari Aspek Kebahasaan, Isyarat Imiyyah Dan Pemberitaan Ghaib (Jakarta: Mizan, 2007). , Membumikan Al-Qur'an; Fungsi dan Peran Wabyu dalam Kehidupan Maysarakat (Bandung: Mizan, 2004). Perempuan: Dari Cinta sampai Seks dan Nikah Mut'ah dari Bias Lama sampai Bias Baru (Jakarta: Lentera Hati, 2005). , Tafsir Al-Misbah: Pesan, Kesan dan keserasian AlQur'an (Jakarta: Lentera Hati, 2002).

Ulfa, Maria, Fikih Aborsi Wacana Penguatan Hak Reproduksi Perempuan (Jakarta: Kompas, 2006). 